\title{
Déwi Malêka: the Javanese Islam manuscript
}

\author{
Zakiyah \\ the Office of Religious Research and Development \\ Ministry of Religious Affairs, SemarangIndonesia \\ E-mail:zaki_smart@yahoo.com \\ DOI: 10.18326/ijims.v6i1.127-160
}

\begin{abstract}
This paper concerns on the Javanese Islam manuscript entitled Déwi Malêka Code Br.16 saved at the National Library of Republic Indonesia in Jakarta and Cod.Or 7562 preserved at the Library of Leiden University the Netherlands. The objectives of this study are to describe the physical condition of the manuscripts and to examine the content of those two texts especially the Islamic and Javanese values. Data was collected using documentary research and analyzed using codicology, philology and Islamic studies. The finding of this research shows that these manuscripts tell about the story of Dèwi Maléka, a queen of Rum. From this story, it can be understood about the Islamic and Javanese values that are presented as questions and answers. In the last chapter of each text, there are some advises related to what should not be done by human being refereeing to the Javanese values.
\end{abstract}

Artikel ini membahas manuskrip Islam Jawa berjudul Déwi Malêka kode Br.16 yang tersimpan di Perpustakaan Nasional Indonesia di Jakarta dan manuskrip dengan kode Cod.Or 7562 yang berada di Perpustakaan Universitas Leiden Belanda. Penelitian ini fokus pada deskripsi kondisi fisik naskah, dan isi dari dua teks tersebut, khususnya terkait dengan nilai-nilai Islam dan Jawa yang 
terkandung dalam teks. Data dikumpulkan dengan menggunakan studi dokumentasidan dianalisis dengan bantuan ilmu filologi, kodikologi dan studi Islam. Temuan penelitian ini menunjukkan bahwa kedua naskah bercerita tentang Dèwi Maléka, ratu negeri Rum. Dari cerita yang dipaparkan dalam bentuk Tanya jawab dapat diketahui bahwa naskah ini berisi tentang nilainilai Islam dan Jawa. Pada bagian akhir teks terdapat nasehat terkait dengan apa-apa yang seharusnya tidak dilakukan oleh manusia. Nasehatnasehattersebut merujuk kepada nilai-nilai Jawa.

Keywords: Islam; Déwi Malêka; Javanese values; Manuscript; Islamic teachings

\section{Introduction}

Java is one of the areas that have produced many kinds of literature. The development of Javanese literature began since $7^{\text {th }}$ century along with the first acculturation process with the Indian culture. It was happened in Central Java and East Java. The culture of India had influenced in three aspects of life namely; (1) religion and knowledge as well as art, (2) society's rule, (3) technology including art and literature. ${ }^{1}$

The second acculturation was happened in accordance with the arrival of Islamic traders in Javanese island. During their trading, these people also disseminated their religion. Initially, this religious dissemination was proposed to common people, and then this activity wasintended to members of the royal family. This activity was conducted during the conflict emerged in the Majapahit kingdom; at that time there were many Javanese scholars converted to Islam. There were many underpinning reasons why this group of people changed to be Muslim such as they are influenced by the Islamic teaching, or they look for their safety. ${ }^{2}$ The next step, Islam took over the entire basic concepts of life including society's rule, literature, art and construction. ${ }^{3}$

\footnotetext{
${ }^{1}$ Edi,Sedyawati. Etall. (ed). Sastra Jawa Sua tu Tinjauan Umum, Jakarta:Balai Pustaka, 2001. ${ }^{2}$ M.Ng, Poerbatjaraka, Kepustakaan Djawa, Jakarta: Djambatan, 1952.

${ }^{3}$ Edi,Sedyawati. Etall. (ed). Sastra Jawa Sua tu Timjauan Umum. Jakarta:Balai Pustaka, 2001.
} 
The peak of Islamic dissemination in Java was occurred during the period of King Brawijaya V (the last king of Majapahid kingdom). ${ }^{4}$ At that time, the king converted to Islam which motivated his citizens to be Muslim. This process of Islamic dissemination had met with the existing Javanese tradition that was influenced by Hinduism and Buddhism. The evidence related with this matter is an old Javanese literature; there are a great number of manuscripts produced such as classical kakawin, babad, Serat, and so forth. In addition, the influence of Islam on the Javanese tradition and the influence of Javanese value in Islam have created two types of Islam in Java namely Islam Java (Islam Kejawen) which is known as an Islamic syncretism, and an Islam pesantren ${ }^{5}$ which is understood as the more purified Islam. ${ }^{6}$

There are many literatures consisting of both Islamic and Javanese values. Djamil (2000) said that Javanese coastal literature is the most influenced by Islam, for example, a manuscript entitled Wejangan Syeh Bari.? In this manuscript there are Al-Ghazali's thought and Junaid al-Baghdadi's notions that explain about mysticisms. Meanwhile, the content of Javanese suburb literatures is more syncretism, for instance, Serat Cebolek manuscript written by Yasadipura that contains about how to reach happiness

${ }^{4}$ M. Hariwijaya, Islam Kejawen, Yogyakarta: Gelombang Pasang, 2006.

${ }^{5}$ Pesantren is an Islamic boarding school.

${ }^{6}$ M. Hariwijaya, Islam Kejawen, Yogyakarta: Gelombang Pasang, 2006; Simuh, Sufisme Jawa; Transformasi Tasawuf Islam ke Mistik Jawa, Yogyakarta: Bentang Persada, 1999. To know this great number of manuscripts, it can be looked at various cataloguessuch as T.E. Behrend, Katalog Induk Naskah-Naskah Nusantara Jilid 4 Perpustakaan Nasional Republik Indonesia, Jakarta: Yayasan Obor Indonesia, 1998; Edwin Weiringa, Catalogue of Malay and Minangkabau Manuscripts in the Library of Leiden Univesity and Other Collection in the Netherlands Volume one, Leiden: Legatum Warnerianum in Leiden University Library, 1998; Theodore, G. TH. Pigeaud. Literature of Java; Catalogue Raisonne of Javanese Manuscript in The Library of the University of Leiden and Other Publict Collection in the Netherland, Leiden: The Hague, Martinus Nyhoff, 1967.

7Abdul Djamil, Perlawanan Kyai Desa, Pemikiran dan Gerakan Kyai Rifa'i Kalisalak, Yogyakarta: LKiS. 2001. 
in life; this text mentions that a human being needs to unite himself with God. This teaching is recognized as manunggaling kawula Gusti. Another literature contains about Islamic and Javanese values is Wirid Hidayat Jati written by R.Ngb. Ranggawarsita. ${ }^{8}$

The strength of Islamic influence to the Javanese literature has created two different types of literature namely; (1) Literature of Islamic santri ${ }^{9}$, and (2) Javanese Islam literature. ${ }^{10}$ One of literatures that is important to be researched is a manuscript entitled "Déwi Malêka". Poerbatjaraka (1950) categorized this manuscript as the literature of Islamic santri. However, text of Déwi Malêka consists of Islamic teaching and Javanese learning written as a poem called macapat. ${ }^{11}$ Hence, this manuscript is more likely as Javanese-Islam Literature. This manuscript was written in pegon (Arabic script and used Javanese language). ${ }^{12}$

It is necessary to study the Islamic and Javanese values described in the text of Déwi Malêka for the reason that this manuscript contains both of

\footnotetext{
${ }^{8}$ Abdul Djamil, Perlawanan Kyai Desa..., 162-167; S. Soebardi, The Book of Cabolek: A Critical Edition with Introduction, Translation and Notes: AContribution to the Study of Javanese Mystical Tradition, The Hague: Martinus Nijhoff, 1975.

${ }^{9}$ Santri means the student of pesantren (A.G, Muhaimin. "Prelude", in Tradition and Change: In Indonesian Islamic Education. Zamakhsyari Dhofier, Jakarta: Ministry of Religious Affairthe Republic of Indonesia, 1995). Besides, there are manyviewsabout the origin of the term santri such as an opinion that the world santri is originally from the world Shastri (Sanskrit language) means an expert of Hinduismbook or an expert of the religious andscience books, while others say that the word santri come from Tamil language meant religious teacher (Joko Suryo, Tradisi Santri dalam Historiografi Java: Pengarug Islam di Jawa, Paper presented at Seminar on Pengaruh Islam terhadap Budaya Jawa, November 30, 2000). Furthermore, in Indonesian dictionary, santri means people who devout seriously or peoplewho study Islamic teaching (Tim Kamus besar Bahasa Indonesia, 1997). In this case, santri is defined as the people learning Islamic teaching in the pesantren (Islamic boardingschool).

${ }^{10}$ Simuh, Mistik Islam Kejawen Raden Ngabehi Ronggowarsito Suatu studi terhadap Serat Wirid Hidayat Jati, 1988.

${ }^{11}$ M. Ng. Poerbatjaraka, Kepustakaan Djawa, Jakarta: Djambatan, 1952.

${ }^{12}$ Theodore, G. TH. Pigeaud, Literature of Java; Catalogue Raisonne of Javanese Manuscript in The Library of the University of Leiden and Other Publict Collection in the Netherland, Leiden: The Hague, Martinus Nyhoff, 1967.
} 
those values. By examining these aspects, it will be understood how Islamic and Javanese values have influenced each other. This article, therefore, discusses these two aspects; how is the physical condition of the manuscript, what are the Islamic and Javanese values in the text of Déwi Malêka.

\section{Literature review}

There are many studies discussing about manuscript of Dèwi Maléka, to name among those scholars are; a team research affiliated with general directorate of culture in Jakarta (1992) studied the manuscript of Dèwi Maléka code Br.16. This research aimed to provide a texts edition, translation and transliteration. In this study, firstly, they wrote a brief description of the physical condition of such manuscript. Secondly, they made transliteration from the Arabic script (pegon) into Latin script. Thirdly, they translated the text from Javanese into Indonesian, and then they described the content of the text. This is a library research using a descriptive qualitative method. Finding of this research stated that this manuscript seemingly came from the pesantren, ${ }^{13}$ this can be seen from the core content of the text that depicted about Islamic teaching. The researchers refer their argument to Simuh's idea that pesantren's literature mostly talked about syari'at (Islamic learning). In this case, they defined syari'at as rules created by God for human's guidance, specifically to direct them when they interact with God, human beingsand other creatures. ${ }^{14}$

Pudjiastuti (2006) wrote an article called "Dèwi Maléka sebuah Model Karya Sastra Islam Jawa". This writing is one of the chapters in her book entitled Naskah dan Studi Naskah. This chapter examines a manuscript

\footnotetext{
${ }^{13}$ Pesantren is an Islamic boarding school.

${ }^{14}$ Tim Peneliti Direktorat Jenderal Kebudayaan Jakarta, Serat Dewi Maleka, Jakarta: Proyek Penelitian dan Pengkajian Kebudayaan Nusantara Direktorat Sejarah dan Nilai Tradisional Direktorat Jenderal Kebudayaan, 1992.
} 
"Dèwi Maléka" code Br.16 saved in National library of Indonesia. It is started with a brief description of physical condition, followed by a summary of the content and an explanation of Islamic teaching in the text. The explanation of such teaching are described using a question-answer type similar to the original text, there are a hundred questions related to Islamic teaching. ${ }^{15}$

Drewes (1986) wrote an article entitled the Story of Dèwi Maléka. Drewes said that the story of Dèwi Maléka is in a manuscript code Cod.Or 2051 dated $1748 \mathrm{H}$ (1820 AD). He stated that there are other two copies of such manuscript namely Cod.Or 7562 and Br.16. The first two manuscripts are saved in the library of Leiden University and the rest is saved in the National library Republic of Indonesia. He mentioned that the story in those manuscripts resembled with the story of Samud, although its setting is different. ${ }^{16}$ Similarly, Weiringa (1994) also mentioned that at least there are three manuscripts containing the story of Dèwi Maléka namely Cod.Or 2051, Cod.Or 7562, and Br.16. ${ }^{17}$

Weiringa (1994) explained that in Urdu the story of Dèwi Maléka is known as a pious queen from Egypt. It is told that the king from Egypt named Firoz passed away; he has a pious wife resided in the palace. After ruling the kingdom, this wife as a queen announced that she will marry anyone who can answer her 100 questions. She will give her throne to such man. Many people came and tried to answer the questions and all of them failed. One day, there was a wise man named Abd al-Alim who was able to answer all the questions, and then finally they got married. Weiringa emphasized that although there aresome differences, the essence

\footnotetext{
${ }^{15}$ Titik Pudjiasuti, Naskah dan Studi Naskah, Bogor: Akademia, 2006, 88-168.

${ }^{16} \mathrm{G}$. Drewes, "Javaneseversions of the Questions of Abdallah b. Salam," Bijdragen tot de Taal Land-en Volkenkunde, Vol. 142 No. 2/3, (1986), 325-327.

${ }^{17}$ Edwin Wieringa, "The Javanese story of Dywi Malyka; A Tran sformation of a Persian or Perso-Urdu tale”, Bijdragen tot de Taal, Land-en Volkenkunde, Vol. 150 No. 3,(1994), 584-587.
} 
of the story was the same. The Urdu poem based on the Persian poem, it dated 11 Safar 1100 H / 5 December 1688. The story of Dèwi Maléka was also similar to the story in Urdu entitled Risalah-e-Sawal-o-Jawab. ${ }^{18}$

\section{Conceptual framework}

This study focuses on the text of Déwi Malêka, providing with reviews of the physical condition and evaluation of the content of the text. Therefore, philology, codicology, and Islamic studies as well as Javanese studies will be utilized for this purpose. To give an overview of these frameworks, here will be explained each of the concepts; Firstly, Philology is defined as the knowledge about literature including language, letters, and culture. The term of philology is derived from the word philos means "love" and logos means "words", so that philology means love of words. Then, this meaning changed into "love of learning" and "love of culture". ${ }^{19}$ The object of the philology is manuscripts. Manuscript is a hand written document that are inherited by ancestors and written on the paper, lontar (palm leaf), beaten bark of trees, and beaten bark paper called dluwang. ${ }^{20}$ In this study, philology is intended to know the messages (Islamic and Javanese value) in the text of Déwi Malêka, as one of the functions of philology is to understand the message of the text. ${ }^{21}$

Secondly, to describe the physical condition of the manuscript, this research used acodicology which means knowledge learned about the manuscript not the text. ${ }^{22}$ Refereeing to codicology, there are many aspects that can be looked at manuscripts such as the history of the manuscripts, the

\footnotetext{
${ }^{18}$ Edwin Wieringa, "The Javanese story..., 584-587.

${ }^{19}$ Nabilah Lubis, Naskah Teks dan Metode Penelitian Filologi, Jakarta: Forum Kajian Bahasa \& Sastra Arab, Fakultas Adab IAIN Syarif Hidayatullah, 2007.

${ }^{20}$ Edwar Djamaris, Metode Penelitian Filologi, Jakarta: Manasco, 2002: 3.

${ }^{21}$ Nabilah Lubis, Naskah Teks dan Metode Penelitian Filologi, Jakarta: Forum Kajian Bahasa \& Sastra Arab, Fakultas Adab IAIN Syarif Hidayatullah, 2007.

${ }^{22}$ Titik Pudjiasuti, Naskah dan Studi Naskah, Bogor. Akademia, 2006.
} 
history of manuscrpt's collection, the use of manuscripts and the description of physicalcondition of the text such as the size of manuscript, total of the pages, number of manuscripts, type of script, language, and so forth. ${ }^{23}$ Meanwhile, in this study, there are two elements that are described namely the history and physical condition of the selected manuscripts.

Thirdly, content analysis is applied to examine the Islamic and Javanese values in the text of Déwi Malêka because this research focuses on theideas and notions that stated in the written document. Content analysis is atype of qualitative analysis in which researcher makes categorizations of the data. ${ }^{24}$ These categorizations include the description of the similarity and the difference between those two manuscripts Br.16 and Cod.Or 7562 as well as the explanation of the Islamic and Javanese values in the texts.

\section{Research method}

This study is a qualitative research, and data are collected using library research. It focuses on examining the physical condition of the manuscripts entitled Déwi Malêka. Then, how the story described in the text is evaluated. After that, the content of the text is analyzed using Islamic studies and Javanese studies. Meanwhile, Objects of the study are two Déwi Malêka manuscripts namely Déwi Malêka code Br.16, saved in the National Library Republic of Indonesia and Cod.Or 7562 saved in the Library of Leiden University the Netherlands.

\section{Overview and description of the manuscripts}

Based on the catalogues and other writings, it is understood that there are at least four manuscripts under the title Dèwi Maléka as follows; two

\footnotetext{
${ }^{23}$ Dewaki Kramadibrata, Metode Penelitian Filologi, materi dipresentasikan pada Diklat Penelitian Naskah Keagamaan yang diselenggarakan oleh Balai Diklat Tenaga Teknis Depag, 1 November 2007- 6 Desember 2007.

${ }^{24}$ Christine R. Marlow, Research Methods for Generalist Social Work, Toronto: Brooks/ Cole, 2001, 223.
} 
manuscripts saved in the National library of Republic Indonesia namely code Br.16 and Plt.8; two manuscripts saved in Leiden University library Cod Or 2051 and Cod Or 7562.25

Manuscript Br.16 is a Javanese version written in pegon (Arabic letter and Javanese language), Plt. 8 is a Sundanese version written in Roman letter and Sundanese language. Meanwhile Cod.Or 2051 is written in Javanese letter and Javanese language (hanacaraka) in 1749 H (1821 A.D). Cod.Or 7562 is written in pegon copied in 1894 AD. Beside those four manuscripts there is a copy of manuscript code Cod.Or 10.770 made by A.D Soegiarto in 1936 AD. This is a Romanized version of manuscript code Cod.Or 7562. ${ }^{26}$ From those four manuscripts, this research concerns on two manuscripts, namely; Déwi Malêka code Br.16 and Cod.Or 7562 as follows:

\section{Déwi Malêka Br16}

Manuscript called Déwi Malêka code Br.16 is a collection of J.L Brandes saved in the National Library of Republic of Indonesia. ${ }^{27}$ Generally this manuscript is in good condition and readable. There are many holes in some part of the pages because it was eaten by moth. The text is written in pegon using black ink. The text is written in tembang macapat on the European paper. There is no watermark, chain line and laid lines in it.

${ }^{25}$ T.E. Behrend, Katalog Induk Naskah-Naskah Nusantara Jilid 4 Perpustakaan Nasional Republik Indonesia, Jakarta: Yayasan Obor Indonesia, 1998; Edwin Weiringa, Catalogue of Malay and Minangkabau Manuscripts in the Library of Leiden Univesity and Other Collection in the Netherlands Volume one. Leiden: Legatum Warnerianum in Leiden University Library. 1998; Theodore G.TH. Pigeaud, Literature of Java.

${ }^{26}$ T.E. Behrend, Katalog Induk; Theodore G.TH. Pigeaud, Literature of Java; Titik Pudjiasuti, Naskah dan Studi Naskah. Bogor: Akademia, 2006; Tim Peneliti Direktorat Jenderal Kebudayaan Jakarta, Serat Dewi Maleka. Jakarta: Proyek Penelitian dan Pengkajian Kebudayaan Nusantara Direktorat Sejarah dan Nilai Tradisional Direktorat Jenderal Kebudayaan, 1992.

${ }^{27}$ T.E, Behrend. Katalog Induk Naskah-Naskah Nusantara Jilid 4 Perpustakaan Nasional Republik Indonesia. Jakarta: Yayasan Obor Indonesia. 1998 
The size of the manuscript is $21 \times 16.2 \mathrm{~cm}$ and the text size is $14 \times 11.7$ $\mathrm{cm}$. It consists of 95 pages. Most of pages comprise of 12 lines except for the page 1 and 2 that contain 10 lines. Meanwhile, in the page 95 there are 12 lines with the cone model. There is a frame in each of pages. The size of the out frame is $15.8 \mathrm{~cm} \times 12.1 \mathrm{~cm}$, while the size of inside frame is $15.3 \mathrm{~cm} \times 11.7 \mathrm{~cm}$. This manuscript is bound with a black cellophane tape and covered by a brown thick cartoon. It seems that the cover is not the original cover of such manuscript. There are two pages (page 1 and 2) detached from the binding. The first and the second page are illuminated with the floral pictures.

There is no information about the author and or the copyist. In addition, the time of the text was written or produced was not recognized. There is an unreadable table of content that is placed before the first page, it was written in Roman script; this page was loosed from the binding. In the text there is an Arabic script $(; /$ a letter of Arabic alphabet representing glottal stop), this script plays as the symbol of stop for each sentence.

The text consists of six pupuh (chapters) namely; Asmarandana, pangkur, dhandhanggula, sinom, asmarandana, dhandanggula. Name of the first chapter is mentioned in the first part of the chapter written on the top of page. Meanwhile the rest of the chapter's name is not written clearly in the first part of the chapter. It is written in the last sentence of the previous chapter or in other word called as sasmitaning tembang; for instance, the name of the second chapter is stated in the last sentence of the first chapter and so forth.

The last chapter embraces pepali (prohibition) offered by Ki Ageng Sela which is proposed for marriage advises. There is a catchword in each odd page. In the margin of each page there is a number in Roman script referred to the number of verses of the tembang macapat (macapat song). 
In page 94 there is a cross line using red ink on the word pupuh; under this word there is a word in Roman script "pepali".

\section{DéwiMalêkaCod Or 7562}

Manuscript entitled Déwi Malêka code Cod Or 7562 is a collection of Christian Snouck Hurgronje saved in the University Library in Leiden University. This manuscript is a copy of Priangan Manuscript dated 1283 $\mathrm{H}$ or 1866 A.D. The information about this date is stated in the first page. In addition, in the margin there is an additional explanation written in Roman script mentioning about it.

This Manuscript was romanized by Soegiarto under the code Cod.Or 10.770 saved at the library of Leiden University the Netherlands. Both of these versions, Cod.Or 7562 and Cod.Or 10.770, have its micro film under the code R.17.444 and R.14.940 respectively. Physically, Cod Or 7562 is in good condition and readable. It consists of sixty one pages inscribed with eleven lines of pegon. The text was written on the paper using black ink. In the cover page there is a sentence "mal 2335" written on a white sticker. In the page before the first page there is a sentence "Regaat Prof.Dr.Snouck Hurgronje 1936" written on the white sticker. The size of this manuscript is $17.6 \mathrm{~cm} \times 23.4 \mathrm{~cm}$, and the text size is $11 \mathrm{~cm}$ $\mathrm{x} 14.7 \mathrm{~cm}$.

The manuscript is covered with a green thick paper and bound by a black cellophane tape. There are catchwords in certain pages which are at page 16, 32 and 48. There is no information about the author or the copyist. In the last page of manuscript there is information given by Snouck Hurgronje mentioning about this manuscript, here are the sentences "Soeloek(tembang), Priangan regentseh (1894). Theologische en mystieke antwoorden van den goeroe Abdoel Azim uit Katem of Katem in Mesir op vragen van Ratna Maleka, voratin van roem. Aan het a lot: verklaringen van eenigne gehemzinnige uitdrukingen” 
Those Hurgronje's sentences give a brief explanation that this manuscript is about soeloek/tembang contained mysticism teaching; it tells about Déwi Malêka and Abdul Azim. Déwi Malêka is a queen of Rum creating a competition. Abdul Azim is a prince from Katem Egypt who participated in the competition and succeeded answering all of the questions.

There are many margin notes given by a reader. The reader underlines the word in the texts using a pencil and gives explanation in the margin. In addition, there is also a tick as a symbol that the reader corrects the word. In this case, it seems that the copyist did it because the ink and the script are similar to the ink and script in the body of text. Here are all of those notes and correction;

Table 1 The Correction and Margin notes

\begin{tabular}{|c|c|c|c|c|}
\hline Dayrs & line & Ihe onigine af ilus & Thi: เnтts & Wararin mates \\
\hline 4 & 가 & 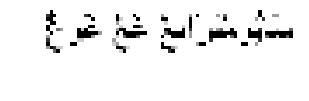 & 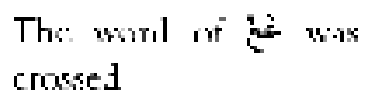 & $\begin{array}{l}\text { Smp nbals } \\
\text { mugnes }\end{array}$ \\
\hline 4 & $i$ & $\therefore$ & 7. Inderlining the pot & [1udurunes \\
\hline $\overrightarrow{7}$ & 5 & ت & 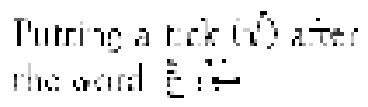 & sts \\
\hline 6 & 10 & كالجنز.ن' & -Interlining r:- wort & ku:tjucupripa \\
\hline$i$ & ; & 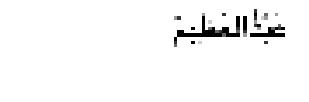 & - & 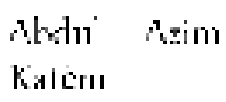 \\
\hline 9 & 11 & تنا & Inde!llnlng r.ent & Mira \\
\hline $1 \overline{3}$ & $\ln$ & 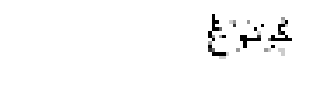 & 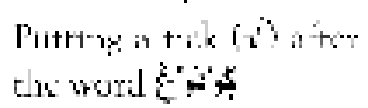 & : بt: \\
\hline 16 & 8 & تا & Jnderlongend & Sara \\
\hline 15 & $?$ & بينت & 7 Inde riming r & Sirroil \\
\hline $\ln$ & 9 & سلبك" & Inderlnlng rine sert & $\operatorname{san}$ \\
\hline 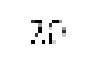 & $\overline{7}$ & E & 7 Indelimm & 45 \\
\hline 21 & 16 & 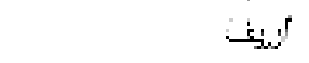 & 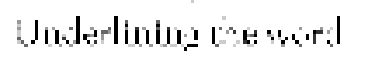 & Arip \\
\hline 27 & 1 & $\because=$ & Goving the wom & ثز \\
\hline
\end{tabular}




\begin{tabular}{|c|c|c|c|c|}
\hline L'яне & line & "Ihe riging of the & 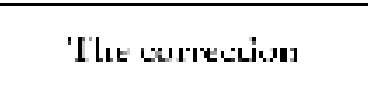 & 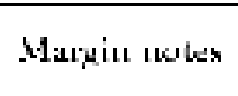 \\
\hline$\because$ & 1 & - & Intedining tor mot & تئ... \\
\hline+1 & 11 & 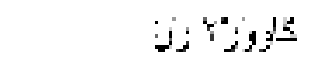 & Inderlining tawal & Guwporin \\
\hline $4 \mathrm{r}$ & $\therefore$ & 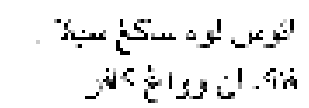 & $\begin{array}{l}\text { liosing riner } \\
\text { sitbiu. }\end{array}$ & wirs magin \\
\hline 18 & $\varepsilon$ & إ: نـ" & 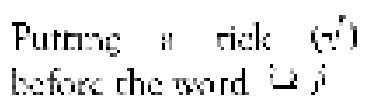 & تز: \\
\hline 51 & $\theta$ & قُنَا & 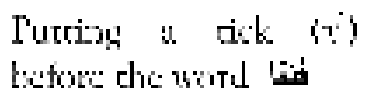 & sis \\
\hline 56 & 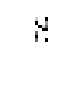 & $\because$ & 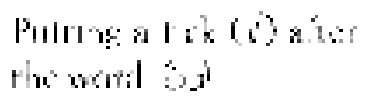 & ب": \\
\hline
\end{tabular}

From the above table it can be said that there are three kinds of corrections and margin notes; the first is a correction by underlining and crossing the word; then the reader or the copyist gives the correct word in the margin note. The second is a correction by putting a tick $(\sqrt{\square})$ before or after certain word as a sign that there is a missing word, after that the copyist or the reader adds the missing word in the margin note. The third is a correction by crossing the sentence, the reader or the copyist does not give a margin note.

In this text, there are two different types of correction; firstly a correction was given by the copyist with the characteristic as follows; thecopyist used the same ink and similar script when writing the word in the margin note. Secondly, the reader made corrections by underlining the word and or crossing the sentence, after that the reader wrote a note in the margin using Roman script and pencil.

\section{Comparison of the content between Cod Or 7562 and Br 16}

Generally both manuscripts talk about the same story namely the story of Queen Déwi Malêka. She is a beautiful, perfect, knowing her responsibility, continually worshipping, patient and wise, good at many sciences 
such as Javanese and Arabic teaching. After the death of her father, Déwi Malêka becomes a queen of Rum. Déwi Malêka wants to have a good, wise and pious husband. To get her husband Déwi Malêka held a competition. She makes a hundred questions which should be answered by the contestants. Whoever is able to answer all the questions will be her husband and will be a king of Rum. On the other hand, whoever can not answer the questions will be killed.

It is told that there is a contestant named Ngabdul Ngalim from Turkestam Egypt. He is a king from Egypt who pretends to be a poor person. He is smart, wise, and pious. Ngabdul Ngalim can answer all of the questions precisely. To answer some of the questions he gives arguments with references to relevance passage of the Qur'an. Déwi Malêka and Ngabdul Ngalim get married. In the last part of the story, there is married advises given by Ki Ageng Sela (Déwi Malêka's teacher). During the interview, Déwi Malêka asks many questions containing Islamic teaching. In this story, it also contains some Javanese values.

Although in general those manuscripts contain the same story, in the detail there are many differences. Here are some examples of the detail similarities and differences:

\section{Similarities of the content (Br.16 and Codor 7562)}

o The story of Déwi Malêka, a queen of Rum

o The main character in the Story; Déwi Malêka and the king of Egypt ( $\mathrm{Br} 16$; Ngabdul Ngalim. Cod.Or 7562; Abdul Azim). He is a young handsome man, single and wise man.

o Ngabdul Ngalim/Abdul Azim walks to Rum for four days and nights. During his journey, he has never forgotten to take daily prayer.

o The chief minister to queen asks Ngabdul Ngalim/Abdul Azim about his origin. He answers that he comes from Turkestam (Br 16) / Katem (Cod.Or 7562) Egypt. 
o Ngabdul Ngalim/Abdul Azim serves with many kinds of food and snack completed with the sweet drink.

o Firstly, Déwi Malêka asks him to recite this sentence;

o The queen asks him to complete his answer with references from Qur'an. She said that knowledge without a teacher is a taklid belong to the evil.

o The queen asks him; where is your place? He answers; my place is cemetery

o The beautiful queen asks him: what is created? He answers; devils

o The queen asks him; what has never seen its creation? He answers; the Prophet Musa's comb

o The queen asks him: who are created without father and mother? He answers: there are five creatures namely Prophet Adam, Eve, and Prophet Sholeh. (The rest is different between Br.16 and Cod.Or 7562).

o The queen asks him again; there is a tree having twelve branches, a branch has thirty leaves, the colors of the leave are white and black. He answers that a tree having twelve branches is twelve months, thirty leaves means thirty days in a month, white and black leaves means a day and a night.

o The queen asks him again: what is previously created? He says he is son of prophet Adam named Qabil.

o The queen asks him again: how manybooks were passed. What books are famous, and what books are mansukh (abrogated). The poor says: there are 104 books, four books are famous, teen books are mansukh. Torah belongs to Prophet Moses, Bible belongs to ProphetIsaac, Zabur belongs to Prophet Dave, Qur'an (Furqan) belongs to Prophet Mohammad.

o The queen asks him again: how many prophets are they? How many prophets are they as messengers? How many prophets with the religious teaching (syari'at) are they? How many prophets with the religious teaching (syari'at) but without a [holy] book are they?

o He answers the questions: there are saketi kalih lekas, three thousand prophets (Cod Or 7562), four thousand prophets ( $\mathrm{Br} 16)$. There are three hundreds and thirteen prophets as messengers, there are six prophets with the religious teaching namely prophetAdam, Nuh, Abraham, Moses, Isaac, Mohammad.

o Prophet with syari'at (religious teaching) but without a book is Prophet Noah. 
o The meaning of prophet is a person who got wahyu (divine inspiration/ revelation) during his dream. While the meaning of prophet as a messenger is a person who gotlove from God through the Gabriel.

o Ngabdul Ngalim /Abdul Azim have been in Royal palace for a long time. He is jailed by Dêwi Maléka. Notall of the questions have been answered. He stays in a small mosque, many staffs and village leaders serve him, many old and young men guard him. All of them are happy, and they compete to serve him. The situation is similar to mmantu (a special event like wedding ceremony, birth ceremony).

o Because the queen is proposed, so that all people are happy. There are colorful ointments; yellow, red and white (Cod.Or 7562), its colorful ointment; yellow, blue and green (Br. 16).

o All people change their cloths. Ngabdul Ngalim/Abdul Azim is given a penghulu (a clergy man) with the white cloth. Ngabdul Ngalim/Abdul Azim wears an invaluable cloth. He is suitable to be a king.

o The queen asks him to follow what she intends to do. She asks him again: who does the prophet become a king? He answers: there are nine prophets namely Prophet Sholeh, Prophet Hud, prophet Ishak, prophet Dave, prophet Solomon, and Prophet Mohammad. (In Cod. Or 7562, it is stated Prophet Moses, while in Br.16 it is stated Prophet Joseph). Both of the manuscripts mention only seven prophets.

o The queen asks him again: who are the great king with many soldiers? He answers that there are three kings as follows, Prophet Joseph, Prophet Solomon and Ngabdul Karnain.

o The queen asks him again: who are the infidel king? He says; there are three kings namely Pharaoh, Tsadah, and Namrud.

o The queen asks him again, what is oneness? He answers. It is the existence of Allah (God).

o The queen is smiling and asking him again; what are the four matters? He answers that the four matters consist of fire, wind, water, and earth.

o There are five ways namely syahadat, prayer, zakat (almsgiving), fasting during the month of Ramadhan, and hajj (pilgrimage).

o The queen asks him again, what is in seven? He says; earth in seven, sky in 
seven, heaven in seven and hell inseven.

o The queen asks himagain: what is created one the same as created teen? He says: it is amal (action) which is rewarded ten times.

o The queen asks him again: where are the place for prophets' living? He answers: prophetIdris and Prophet Isaac are on the sky with angels. Prophet Ilyas lives in earth, he goes around the earth. Prophet Hidlir lives on the sea, he goes around the sea.

o There are people (kamasan) who lie in buying and selling products, they are cursed to be a bat.

o There are people who do not take compulsory bath such as wiladah (bathing after giving birth), nifas (bathing after the end of nifas/approximately three months after giving birth), and haidh (bathing after having menstruation) will be cursed.

o There are babilpeople who participated in blowing fire during the Abraham punishment are cursed to be dolphin

o In the era of Prophet Adam, there were people who loan to others, and they decrease the amount of loan when they gave it back, these people were cursed by Prophet Adam to be pigs.

o The queen asks him again: where is the place of (ngusik), the place of passion, and the place of breath. He says that the place of passion is in a heart, the place of breath is betal makmur, the place of logic in the brain.

\section{The differenceof the Content}

Here are some examples of the difference:

\begin{tabular}{|c|c|c|}
\hline & $\operatorname{cod} 0 \times 7561$ & Br-Iti \\
\hline 0 & Stated rich a sentance & a staited xith a sentance \\
\hline & 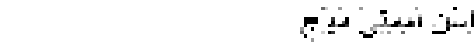 & 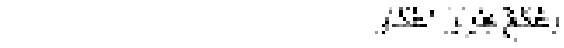 \\
\hline 0 & Atter the aloure sentense, it is & 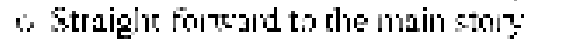 \\
\hline & 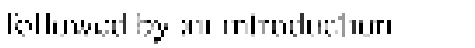 & \\
\hline & 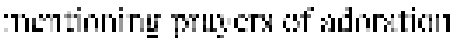 & \\
\hline & 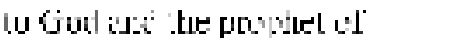 & \\
\hline & 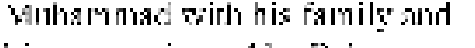 & \\
\hline & 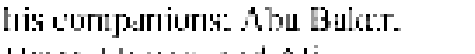 & \\
\hline & 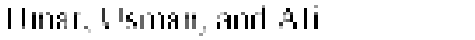 & \\
\hline
\end{tabular}




\section{God or 7562}

1

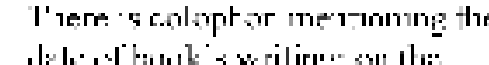

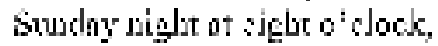
Pluhiariom, 8,12931 I.

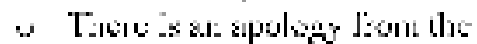

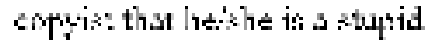

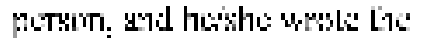
ecript bindly.

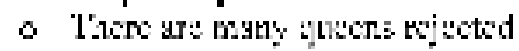

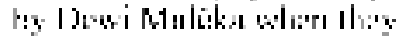
mopred her:

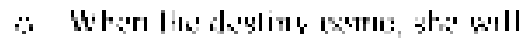
ot in wried

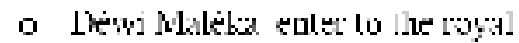
minco:

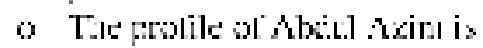

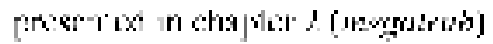

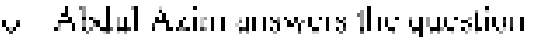
thist he commes Amor latem I By:

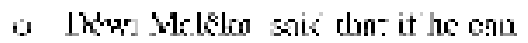

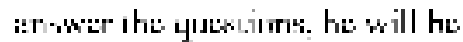
cridos mith the atute of Rula.

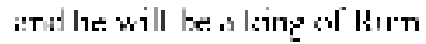

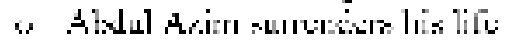
ard his denth to the orecen, boumse he belisuse the it i:

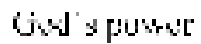

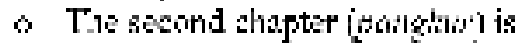

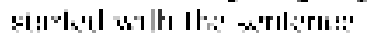

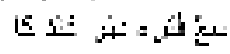

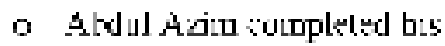

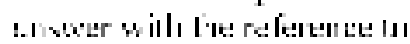
Qur'un ifor the question; where

\section{Th'. 16}

$\because$ Nalnom

- Momoln

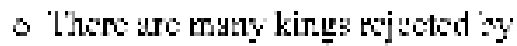

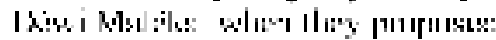
ver

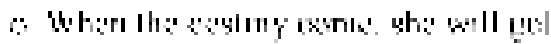

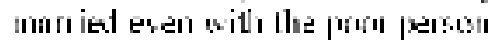

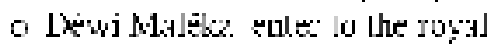

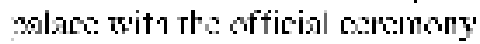

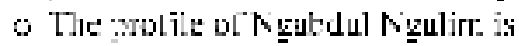
rosilltal irs chajtat 1

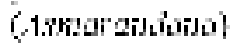

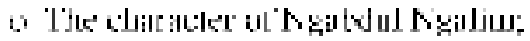
wife a nit atile to answer the

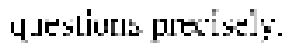

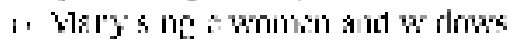
lane Yeribul valini

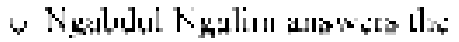
4:ation thill he cilmeis tron Tukbulau Ekipl

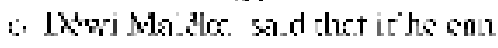

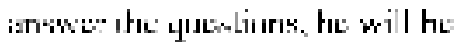
croudol sith to tate ol kut

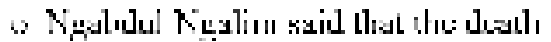
is a geses inentian.

o The thind ohapter imathorl is

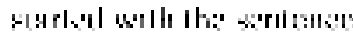

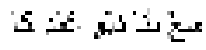

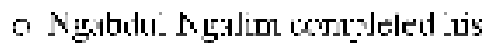

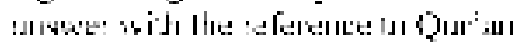
tor the alustior; where are you 
are yultom

$$
\text { 2. }
$$

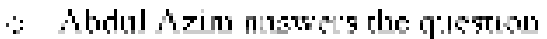

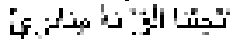

$\therefore$ Ahdul him wlats:s the

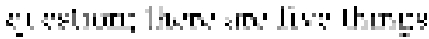
tancely Frophet Adirn mith The,

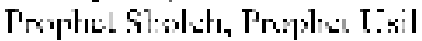

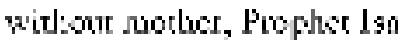

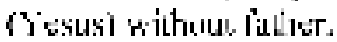

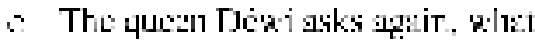

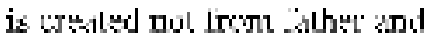

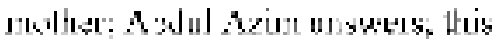
if Adom and his wite, Prophes

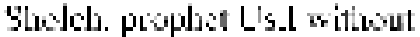

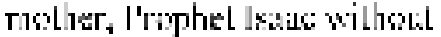
lithe:

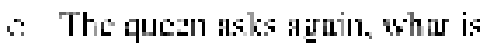
eaten that co:ue from earth. that is:

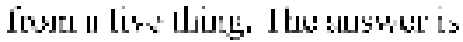
sethetion romed Priphet I:ste Sole by Kali pople.

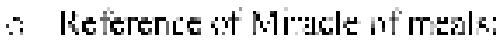

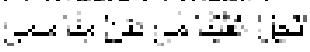

$r$ What is not fromearrli. war is rot from sky" The answer is.

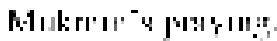

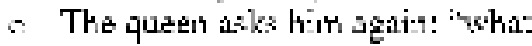

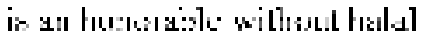

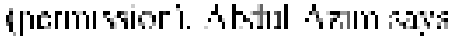

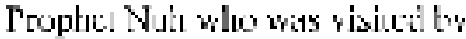
Intrican:

$\Rightarrow$ Where is a camal from? Fom the 1.an thom!

$$
\text { : : }
$$

- vgalodul volire arsuer the 44 ل4:

$$
\text { . } 11: ; 3
$$

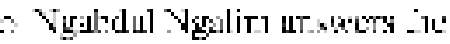

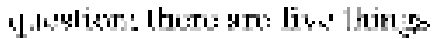
namely Adim and Tire, Fipptest

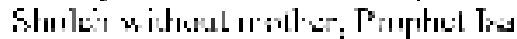

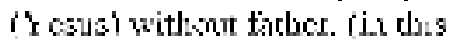
unstite the is mit hur not his

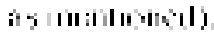

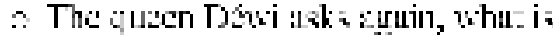

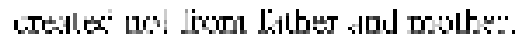

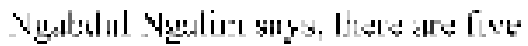

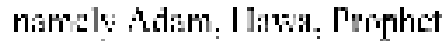
Sbolde without malder. Propliet

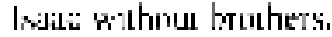

s The cuech ask ipgir. pillat is satel that does wot wore tron sar.le and

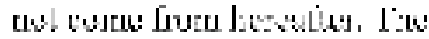

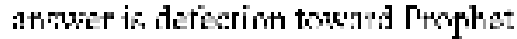

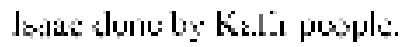

$\therefore$ Keterence of Hillacle of Imeasis

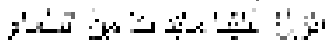

a helat is from sarli, whar is tom

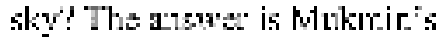
rimint:

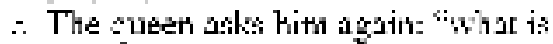

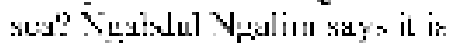
soneth ing fromin the P'pphet Nolh,

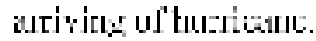

. Valodul Vgalin adid is tion hall m, TI

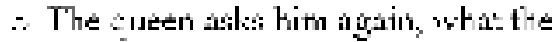
rulererus in. Tlis fun stid

$$
\text { - }
$$

$\ddot{8}$

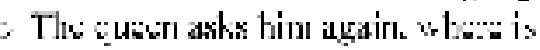

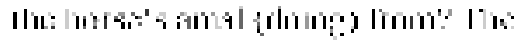

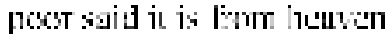


$\therefore \quad-$

$+$

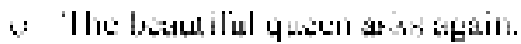
whar dnes ir come nod peiluat dios

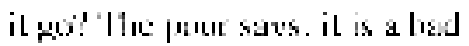
ITr:

1. I"тopier witl bonk of relivions

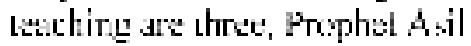
bis tity books Proptet ldr"s bis

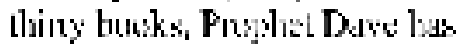

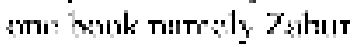

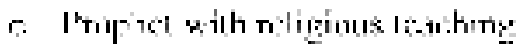

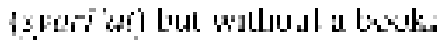

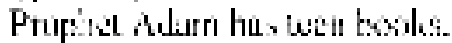

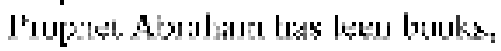

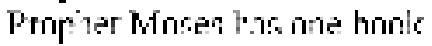
callod I roth. I'rophet laikt has one soole hamed Eible, Piophet

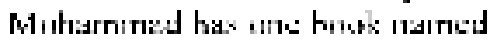
[DII]

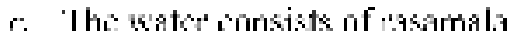
ind kasori, all are compleptad. It

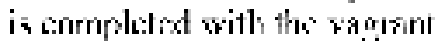
blume:

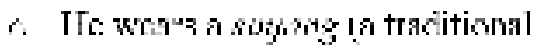
floth lin a dotinly.

$\therefore$ mat ansorine thi a ques-ion!

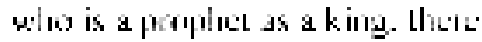
$\mathrm{i}$ ind diftinone: in this manocripe it is stared prophet Mnene!.

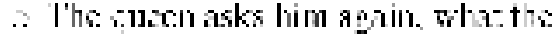
relecerose is. The putur silid

$$
\text { 然 }
$$

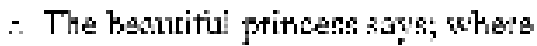

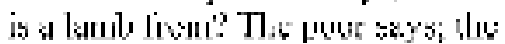

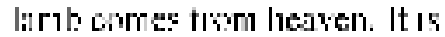

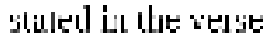

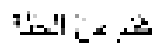

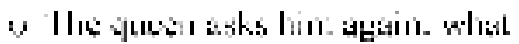
Anc:a it come n nit whar dne ir. gn"

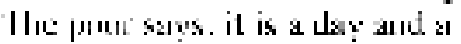
niltat.

o Propises wirl book but without religious: Lutuhing imgriaty are prophet Lsis with titte bocks.

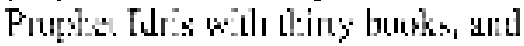

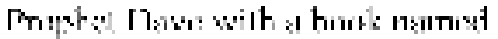
Zzbus.

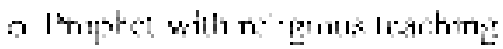

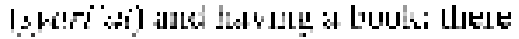

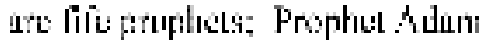

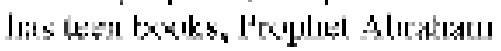
ho rean honls. Propher Mhas hom

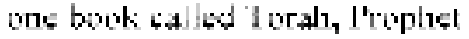
[aud has ois bouk anted Bible prophel chohammad h.sk ine boit. Jastad Ou"in

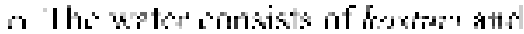

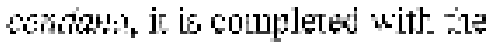
mhata: Thute.

A The vera a kning itracitisnal hat

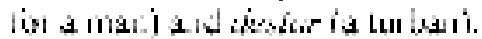

$\therefore$ hher answine this qustion: whō

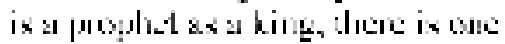

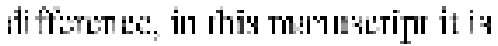
stated pioplist Joseph. 


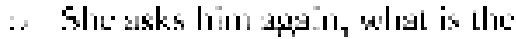

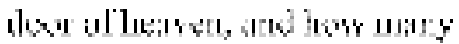

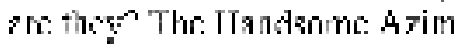

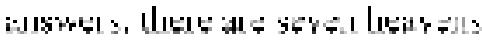

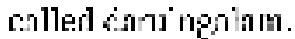

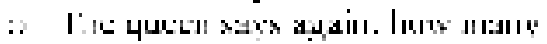

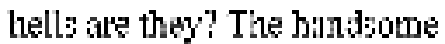

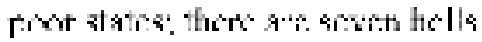

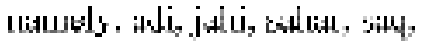
alim: ajin: at andiri

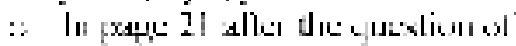

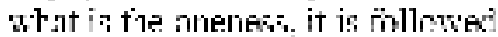

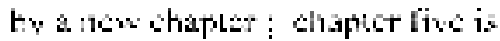

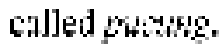

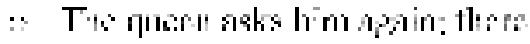
all ronche, what an: the Atsil Noin striles atd anchets; lt: eiglit bractios are -za zupporter

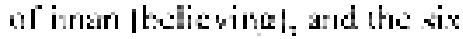

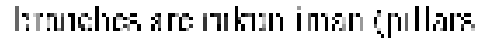
u'blisuriry.

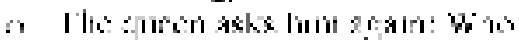
cie the srophet aill alive: There

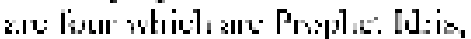

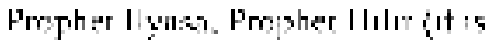

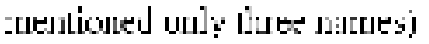

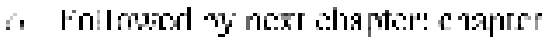

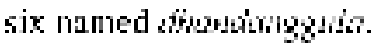

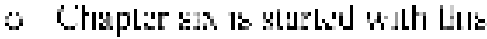
strifince

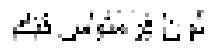

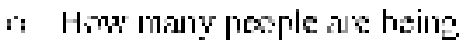
cursed to be tricuits in the wordt!

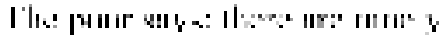

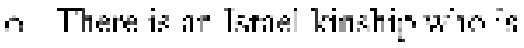

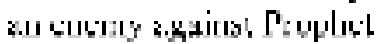
Mohaminal: they are corricil to he zuiutirl.

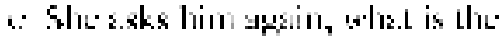

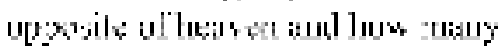

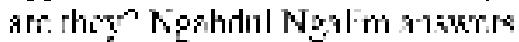

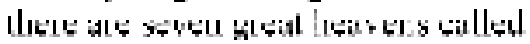
Antusinin.

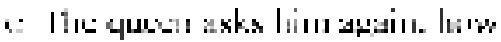

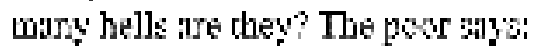

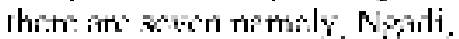

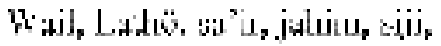
jotharin

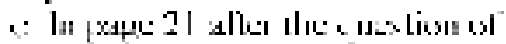

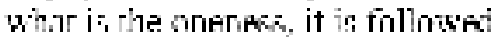
by the nos glustion lthis is still in 山e вате clapty.

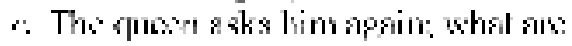

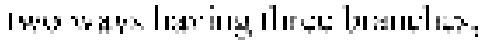

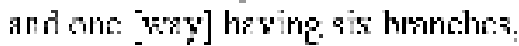
what at the's Abul Mom striles

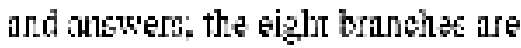

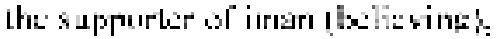

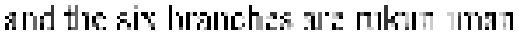
पjille.ri ol bulieringl.

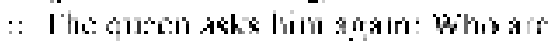
the philhete still alinel There are

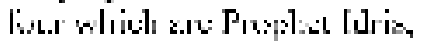

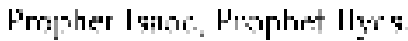
Froplet IItilits

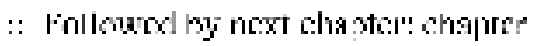

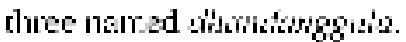

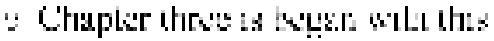
tertintes

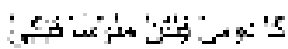

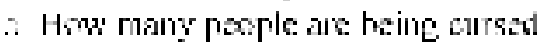
to be animals ju the wotld! " The

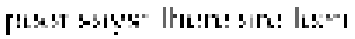

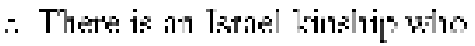

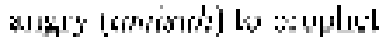

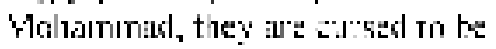

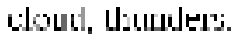


IJIMS, Indonesian Joumal oflslam and Muslim Societies, Volume 6, Number1, June 2016: 127-160

a There nre penple wh sell ari "my thingsing ard they dercase the

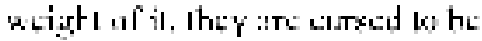
halet

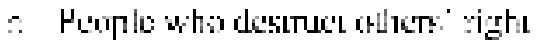
ale avsed to have tace s-wilat to

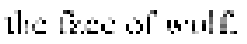

s Thet powple hare loun und hat happe shau Proplet Abritara bial ficed il:

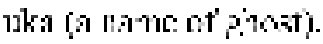

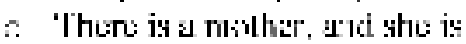

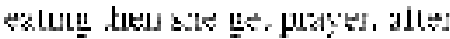

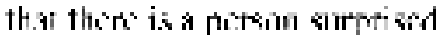
her. This: perm if earnat ly thol Lo tet al tol.

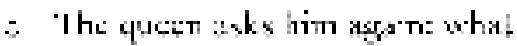

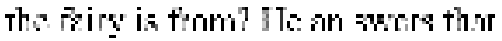
it ist frum the sight ulpumer. a There are nenple uthell and bry

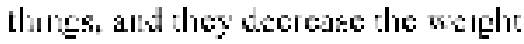

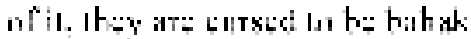

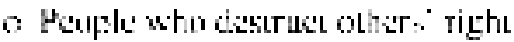

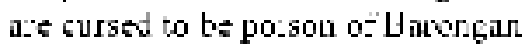

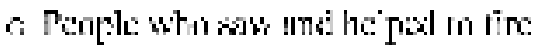
prophe. Ábratera are cure ke be Ulisb-ukadbl it nime of thostl-

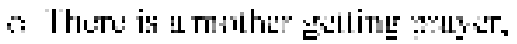

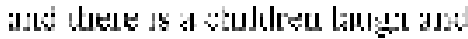

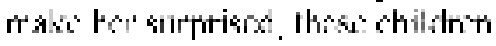
are curted to he bat

C Ihe quet agre whit, is latys

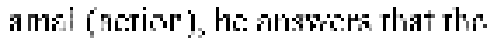
feity :t umal is from atuging.

\section{Islamic teaching and Javanese values in the text of Dèwi Maléka}

Texts of Dèwi Maléka Br. 16 and Cod.Or 7562 concise of Islamic teaching that are described as a form of questions and answers. Besides, there are Javanese values which are explained in the form of pupuh in both manuscripts. Here are those Islamic and Javanese values:

\section{The creation of human being}

It is stated that the first thing to be created in this universe are the script of kaf and nun, as well as human being (Adam and Eve).

Br. 16, pupuh 2:

Ngabdul ngalim tinakonan déné sang nata ing arum sang prabu astari : éh fakir apa rumuhun: didadéakn pangéran: fakir matur kaf klawan nun murodé huruf puniko : lafadz kun fayakun ugi. 
(Ngabdul Ngalim was questioned by a well-known queen Prabu Astari, hi Fakir what is the first to be made by God, Fakir Answers, and it is a letter Kaf and Nun, from the sentence Kun fayakun).

Sang nata maléh ngndika : saking ngndi angsal ira Dul Ngalim: ingkan tinakonan matur: saking labté bapa duk tumts dumunung ana ing bayu: mésm sang prabu wanudya : ana krasa angati.

(the queen asks again, where are you [Dul Ngalim] originally from, he answers, from father's that drops into water, the queen smiles, it feels warm).

Cod.Or 7562, pupuh 3

Abdul Azim tinakonan déning iku iyo ing sang ayu puteri. Hai pekir apo rumuhun Dinadeaken pengeran. Pakir matur. Iyo iku kalawane nun. Karepé nun punika. Inggih kun fayakun ugi. Sang ratna ayu ngendika. Saking endi asalé ing Abdul Azim. Ingkang tinakon umatur. Pan saking wetenging bapa. Duk tumetes. Sinungé garwaning babu.

(Abdul Azim was questioned by the beautiful princess, Hi Pekir, what is to be made firstly by God, Pekir answers, this is a nun, that is meant kun fayakun, the queen speaks, where are you [Abdul Azim] from, he answers, from father's womb that drops to his wife's womb).

Fivepillars of Islam; syahadat, praying ,Zakat (almsgiving), fasting, Hajj. Br.16, pupuh 2

Sang nata malih atanya : éh Ki Pakir apa aran sawiji : pkir kasihan umatur : punika wujud Allah : naténg maléh pamuwusé arum : awit jisim patang prkara : leh iku aranê ugi.

(The queen asks again, hi Ki Pekir what is the one, Pekir answers, this is the existence of God, the queen smiles again, because this is a four matters, that is also stated) 
Fkir ngarip atur ira: kang skawan arané singgih : gni angin lmah banyu : sang nata angndika : ana dlapan lalima kathahé puniku : syéh ngarip atur wcana : inggih lima ingkang margi. syahadat klawan sholat : lawan syiam ing wulan ramadhan singgih : zakat haji limanipun.

(Fekir tells about the four matters, fire wind earth and water, the queen speaks, there are five, Syeh Ngarip answers, yes there are five ways, syahadat and praying, fasting during month of Ramadan, zakat [almsgiving] and the fifth is hajj).

\section{Cod.Or 7562 Pupuh 4-5}

Sang rara ngndika malih. apa ingkang ing aranan. Puniko sawiji2. umat ira fakir kasian. Ing wujud allah kang ykti.

(The queen speaks again, what is the one, your people Fakir speaks, the existence of God).

.... Ki seh urip [arip] Hatur mlas arip arum. Nggih gangsal kang marga. Syahadat lawan solaté. Jakat siyam ing wulan ramadan iko. Munggah haji kaping limané puniku.

(.... Ki Seh Urip told gently, there are five aspects, syahadat and praying, zakat [almsgiving], fasting during month of Ramadan, the fifth is hajj)

\section{Thestory of prophets, thenumber of prophet and their power}

Br. 16

Pirokabéhê ingkang kitab: kangtinurutakn lawan ndi : kitab masyhur kang mansukh : kitab pira satus papat katahipun : kangsatus mansukh sdaya: skawan masyhur puniki. Kitab taurat Nabi Musa: Nabi Isa katurunan kitab Injil: Zabur maring Nabi Daud: Qur'an Nabi Muhammad : linging nata pira nabi kathahipun : lan piro nabi utusan $\therefore$ kang sarêngat piro nabi 
(How many are the books, for whom those books, the famous books that are mansukh [abrogated], there are a hundred and four books, a hundred is entirely mansukh [abrogated], four are famous, book of Taurat for Prophet Musa, book of Injil for Prophet Isa, Book of Zabur for Prophet Daud, book of Qur'an for Prophet Muhammad, then how many are those prophet, how many are those who are categorized as rasul [messenger], who received syari'at).

Kang sarêngat tanpa kitab: ingkang kitab saréngaté tan mawi: ingkang saréngat puniki : nora klawan kitab fakir matur kathahé nabi puniki : pan sakati kalih laksa : kawan éwu kéhé nabi.

(Who received syari'at without a book that is book of syari'at, this [prophet] with syari'at and without book, there are sakati kalih laksa, four thousand prophets).

Lan kéhê nabi utusan : tigang ngatus tigo wlas puniki : kang darbé saréngat iku : mapan nnmkathahé : wastanira NabiAdam, Nabi Nuh - Ibrahim Musa lan Ngisa Nabi Muhammad sinlir.

(and the number of Rasul [messenger], there are three hundred and thirteen, who received syari'at, there aresix [prophets], namely Prophet Adam, Prophet Nuh, Prophet Ibrahim, Prophet Musa and Prophet Isa and the last is Prophet Muhammad)

Kang kitab tanpa sarêngat; pan titiga kang parab Esis : sékt kéhé kitabipun : Idris kang tigang dasa : Nabi Daud katurunan kitab Zabur $\therefore$ kang saréngat tanpa kitab : namung Nabi Nuh puniki.

([prophet] who received a book without syari'at, there are three [prophets] named Esis, there are fifty books, Idris is the thirty, Prophet Daud received a book of Zabur, [prophet] who received syari'at without a book is only Prophet Nuh.

Kang sarêngat mawi kitab: llima Nabi Adam linuwih : kéhê kitabé spuluh : Ibrahim pan sdoso : Nabi Musa sawiji Taurat puniku : Nabi Isa kitab ira : ing aranê Injil siji 
([Prophet] who received syari'at with a book, there are five prophets, Prophet Adam, received ten books, [Prophet] Ibrahim received ten [books], Prophet Musa received a book of Taurat, Prophet Isa received a book called Injil)

Nabi Muhammad satunggal nama qur'an: dênê kang aran nabi: sbab anampani wahyu: salbténg supana: ing aran nabi utusan puniku: sbab $n m u$ sih pngéran alantaran Jabrail [Jibril].

(Prophet Muhammad received a book named Qur'an, someone called a prophet becausehe received revelation within him, and someone called a rasul [messenger] because he received God's grace through Jibril).

\section{Cod.Or 7562, pupuh 3-4}

Lan pira akehé kitab. Kang tinurun pangéran sawiji2 lan ndi kitab kang mashur. Kang masuk kitab sadaya [sdoyo]. Skawan kang masyhur iki. Taurat iku nabi musa. Nabi ngisa katurunan kitab injil. Kitab jabur nabi daud. Qur'an nabi muhammad.linga tana [nata] piro nabi akehipun. Lan piranabi utusan. Kang saréngat para nabi. Kang saréngat tanpa kitab. Ingkang kitab puniku datan amawi. Ingkang saréngat puniku. Lan ora kalawan kitab. Fakir matur. Katahé nabi puniku. Pan sakti kalih laksa.

(how many book are there that were given to a prophet and how many are the famous books, those famous books are four books namely Taurat for Prophet Musa, Prophet Isa received a book of Injil, a book of Jabur for Prophet Daud, Qur'an for Prophet Muhammad, how many prophets are there and how many rasul [messenger] are there who accept syari'at, [a prophet] who obtained syari'at without a book, [a prophet] who obtained syari' at without a book, Fakir says that there are sakti kalih laksa)

Tigang ewu katah nabi. Akéhé nabi utusan. Tigang atus tigang wlas katah nabi. Kangdarbé saréngat iku. Kang nnm nabi saréngat. Ingkang wasto. Nabi adam nuh iku. Ibrahim musa lan ngisa. Kaping nem nabi kekasih. 
(There are three thousand prophets; there are three hundred and thirteen rasul [messengers], [a prophet] who received syari'at, there are six prophets with syari'at namely Prophet Adam Nuh Ibrahim and Isa, the six is Prophet kekasih.

kitab saréngat ttlu. Nabi sil anduweni. Skeh kitab gadahiro. Tigang puluh nabi idris. Nabi daud mung satunggal. Kitab jabur arané ki. Kitab jabur nabi daud. Saréngat tanpo kitab. Nabi nuh kang satunggal. Saréngat tan po kitab. Nabi adam sadasa [sdoso]. Anduwé kitab puniki. Nabi ibrahim sapuluh. Nabi musa kang satunggal. Kitab taurat araniro. Ngisa kang satunggal. Kitab injil araniro. Nabi muhammad satunggal. Kitab qur'an kang ka mashur. Déné kang ora nabi. Yoiku wahyu

(There are three books of syari'at, Prophet sil has it, he has fifty books, prophet Idris has thirty [books], prophet Daud has one [book] called a book of Jabur, syari'at without a book, Prophet Nuh received syari'at without a book, Prophet Adam has ten books, Prophet Ibrahim has ten [books], Prophet Musa has one [book], it is called Taurat, [Prophet] Isa has one [book], it is named Injil, Prophet Muhammad has one [book], it is called qur'an that is famous,

\section{Theobgy; the character of God}

This part explains about the character of God that is complemented with the description of its meaning.

Br. 16

Linging fkir aturê amanis : ingkang dihin sifat wujud ika : nafsiyah ika wastanê kang psti ananipun : kaping kalih qidam puniki ; dihin pan kadihinan ananê Hyang Agung : kaping tiga sifat baqa tgsipun alanggng tan kno rusak: mungguh dzatê pngêran.

(Fekir speaks gently, the first is a character of existence, nafsiyah means the thing that must be existed, the second is qidam, and it means the thing is preceded by the existence of Hyang Agung, the third is baqa means eternal without damage, the essence of God) 
Mukhalafatul lil khawaditsi aprbda lawang kang anyar ; punika uga tgsê : ping lima sifat qiyamu binafsihi jumnng pribadi ; ping nnm wakhdaniyah tgs iku:dzat sifat nur lantaran: kaping pat sifat qudrating Hyang Widi ; tgsê Allah kuwasa.

(Mukhalafatul lil khawaditsi means that it differs from the new one, this is the meaning, the fifth is qiyamu binafsihi that means the existence of himself, the six is wakhdaniyah means the essence of Nur, the fourth is the destiny of Hyang Widi [God], it means that God has power).

Kaping wölu iradat puniki : tgsipun pangêran kang karsa : ping sanga ngélmu sifatê : tgsê pngêran wruh : inggih ghaib ingkang rupi : kang urip kang katah : kang namar kang lambut : nora samar pangulatan : pasti wruh pitung bumi pitung langit : tan knö ginaruhan.

(The eight is iradat, it means that God has intention, the ninth is Ilmu, it means that God knows, including the visible and invisible things, the live and the surrenders, the tangible and intangible, he must see seven earths and seven skies, without doubt).

Dalilipun falghaibi wa syahadati : tgsê puniku : wruh ing nora katonan sifat kaping spuluh : sifat khayah mungguh Hyang Widi : urip tan lawan nyawa : mukhalafah iku : ping swlas sifat sama' tgsipun pngêran amiharsa : datn mawi krana.

(The reason is fal ghaibi wa syahadati, it means, knows of the invincible things which is the tenth character, the character of Hyang Widi [God], live without soul, this is mukhalafah, the eleventh character is sama' that represents understanding).

Kaping rolassifat basor singgih : tgsipun ningali pngêran dahatn wiyösê - mukhal wuta Hyang Agung : tigöwlas kalam puniki tgsê angndika : tan suwara tan huruf: mukhal bisu ing yang sukma : ping patblas qudiran kang kuwasa singgih : mukhal kang aps yang sukma.

(The twelfth is a character of basor, connotes God's seeing, it is impossible that God is blind, the thirteenth is kalam which means speaking, 
with voice and without letter, it is impossible that [God] is mute, the fourteenth is qudiran which means powerful, it impossible that [God] is damage)

Ping limolas muridan puniki tgsipun pngran kang karsa : tan mawi angn 2 mangkê: mukhal kesereng Hyang Agung: andadéakn kang mumkin : iku nmblas sifat 'aliman : tgsêwruh ping pitulassifat khayan tgsipun pngêran lan pasti kang urip : pan nora nyawa.

(The fifteenth is muridan, it means that God has intention, with future expectation, it is impossible that God is hopless, creating the unattainable, the sixteenth character is aliman, it signifies [God's] knowing, the seventeenth nature is khayan which means God's life without soul)

Mukhal kang mati ana nang Hyang Widi ; ping wölulasê samingan punika tgsê kang miharsa kabêh songolas punika : bashiran ingkang ningali : ora lawan nêtêra mukhal wuto iku: rongpuluh mutakaliman ; tgsipun kang ngndika tanpo lathi ; mukhal kang bisu pngran

(It is impossible that God is dead, the eighteenth is samingan that means understanding everything, the nineteenth is bashiran which means seeing, without eyes and it is impossible that [God] is blind, the twentieth is mutakalimun, it means speaking without mouth, it is impossible that God is mute)

\section{Cod.Or 7562}

Sang putri ngandika. Ya sifat kalih dasané. Prwinjiné sawang iku. Ki fakir matur. Amanis. Ngkang dingin punika. Iku sifat wujudwtuné saking nafsiyah. Ingkang pasti. Ananipun qadim iki. Ari ngini ing pangéran. Ngagungakn puniko yang widi. Lan ping tigo. Sifat baqa ika. Pan dgsipun [tgsipun] langgngé. Datan kno owah iku. Uriplanggng datan gingsir. Lan mukhalafah. Lilkhawaditsi iku. Beloaken [bloko] lan perbeda. Lawan sifat. Kang anyar2 puniki. Waqiyamu binafsiha. Lan jnngé iku iku ing pribadi. Wahdaniyat kang aseh dat [dzat] lan sifat [sighot]. Sifat af'al lantarané. Sifat qudrat lan ping pitu. Tgsé Al- 
lah kuwasa. Iradat wing wolu. Pangéran ingkan krsa [krsa]. Kaping sanga. Sifat ngilmu ing weruhi. Tgsé wruh sadaya. Ingkang ghoib kang rumpit puniki. Rupa2 kawantu punika. Agung lmbat tan samaré. Ngulatana pasti wruh. Pitung bumi pitung langit. Tan kna owah. Dalil ipun ngilmu. Watsahadat yksira.

(The princess speaks, the twenty characters, explains one by one, Ki Fakiranswers softly, the first thing is, a character of existence "nafisyah", this is firm, the existence of qadim, this is God, respecting God, and the third is, the character of baqa, it means eternal, which does not change, living eternally and endlessly, and mukhalafah. Lilkhawaditsi is, honest and different from, the character of the new one, Waqiyamu binafsiha, and his personal name, Wahdaniyat that contains essence and character, the character of af'al, and the seventh is the character of qudrat, it means that God is powerful, the eighth is iradat, God has objectives, the ninth is, ilmu means understanding everything, including the invisible things and its detail, many kinds of aspects, every moving must be seen, seven earths and skies, it cannot change, the basis of ilmu, Watsahadat yksira.

Datan samar katingali. Lan sifat kaping sadasa. Sifat hayah pan tgsé hirupingkang darbé. Pangéran mulya. Huip tan lawan nyawané. Muhal ing kna pupus. Sawlas sama' punika. Tgsé sifat sama'. Miharsa yang agung. Ping rong wlas sifat basyar. Tgsipun. Aningali ing yang widi. Tigo wlas sifat kalam iko. Pangandiko ing tgsé. Tan po suwara amuwus. Muhal bisu tan ngalahir. Pat belas qodiran. Kawasa[kuwosa] yang agung. Ping limolas muridan. Karsa Allah. Muhal kasereng yang widi. Iyo iku muhal pisan. Ping nmblas 'aliman sayakti [saykti].tgsipun. pangéran waspada. Lan pitu wlas hayané. Tgse hurip yang agung. Muhal mati ing yang widi. Wolung welas sami'an. Miharsa yang agung.

(It was looked, the tenth character is, hayah means life, the honorable God, living without soul, it is impossible that [God] is dead, the eleventh is sama', indicates understanding incredibly, the twelefth is basyar, means that God is seeing, the thirteenth is kalam, it represents speaking, whitout voice, it is impossible that [God] is mute, the fourteenth 
is qadiran, God is authoritative, the fifteenth is muridan, God intention, the sixteenth is 'aliman, it means that God is alert, and the seveteenth is hayané, it means that God is life, it is impossible that God is dead, the eighteenths is sami'an, God understand).

Ing sangang welas basiron. Tgsipun. Paningal saking yang widi. Lan ora kalawan nétra. Muhal wuto pangéran sayakti [saykti]. Kang maha mulya. Rong puluhé ika. Mutakaliman tgsé. Pangandika ingkang agung. Tanpa lambé sahur naki. Muhal bisu pangéran. Tan bisa nauri iku. Iya iku muhal pisan. Datan nyaur. Pangéran kang maha suci. Iku pan tanda kuwasa

(The nineteenth is basiran, it means, God's seeing, without eyes, it is impossible that [God] is blind, the great of God, the twentieth is, mutakaliman, means God's speaking, without lips, it is impossible that God is mute, it is really impossible if God can not answer, God is the great sacred, it is a symbol of power).

\section{Both manuscripts tellabout other aspects like heaven, hell and death.}

These elements were explained stunningly. In addition, those two texts concise of the types of human being that are cursed by God. Those people are cursed to be variety of animals and other forms in the world. For instance, Bani Israel who disgraced Prophet Muhammad is cursed to be cloud and thunder, a woman who tends to rebel are cursed to be a bat, a person who reduced loan payment during Prophet Adam's era was cursed to be a pig, a merchant whodecrease the weight of the product was cursed to be homeless people, a person who laugh at people's praying was cursed to be a cat.

\section{Texof Déwi Malêka concise ofJavanese values thatare explained ata chap- ter called pupuh}

It depicts at the explanation of wedding ceremony in which mostly refers to the Javanese tradition. Furthermore, the last chapter of Br.16 is pepali that include some advices from Kyai Agung Sela. Meanwhile, the last 
chapter of Cod.Or 7562 comprises of Javanese phrases which has great meaning of Islamic teaching. At thechapter six of Br.16, it includes pepali, many type of deeds that need to be avoided by human being. For instance; do not be greedy, do not bother other people because people who often bother others would die soon, do not intervene other's problems (ojo siro watek dahwen, ojo watek ngaruh aruhi), do not expect too much to others, do not be jelouse, because people commit a bad deed would receive a bad deed as a reply (ojo siro watek dahwen, ojo watek ngaruh aruhi), people should not follow their desires during their lifes.

At the last chapter of Cod.Or 7562 mentions Javanese phrases (pepatah) complemented with its meaning. That explanation would lead readers to be a wiser and to be close to God during their living. Here are some of those Javanese phrases; Huruf kang tanpa sekar (the essence of God/Allah), damar murup tanpa sumbu (the perpetual essence), puteri wilis tanpa wilis (Allah/God is created by himself), anut satek pisan atigasi (alert toward God who has a character of oneness), tanggal kapurnama (feels to have one condition), amyah geni dadamaran (finding science after the existence of science), warangka manjing curiga (before becoming corpse), perahu amot segara (soul after becoming corpse), kuda ngurab ing pandengan (do not be fell burden when seeing God and God's messenger), gugupat luluhur (no existence except the existence of God), tapa kuntul ing layang (alms giving that are taken out from the body), bumi pinudum siti (body has intention), susuring anging (body, soul, breath), madep ngalor selagi ngidul (followers of God), tunjung tanpa telaga (at the time God created Nur Muhammad and it is God's saying at murtabah).

\section{Closingremarks}

Dèwi Maléka Br.16 and Cod.Or 7562 are two manuscripts that have similarities and differences. Generally, the story, setting of the story, and 
figures in the story are the same, but details of each content are difference. Thus, it can be concluded that this manuscript Cod.Or 7562 is not a copy of Br.16, and vice versa. Besides, both manuscripts are different. The general physical condition of the manuscripts is good and readable. Texts concise of Islamic and Javanese teaching which is exposed in an interesting ways, there are questions and answers between queen of Dèwi Maléka and Ngabdul Alim [Abdul Azim]. Moreover, there some advises from Javanese phrases to be a good person.

\section{Reference}

Behrend, T.E. Katalog Induk Naskah-Naskah Nusantara Jilid 4 Perpustakaan Nasional Republik Indonesia. Jakarta: Yayasan Obor Indonesia, 1998.

Dhofier, Zamakhsyari. Tradition and Change: In Indonesian Islamic Education. Jakarta: Ministry of Religious Affair the Republic of Indonesia, 1995.

Djamil, Abdul. Perlawanan Kyai Desa, Pemikiran dan Gerakan Kyai Rifa'i Kalisalak. Yogyakarta: LKiS. 2001

Drewes. G. Javanese versions of the Questions of Abdallah b.Salam. Bijdragen tot de Taal-,Land-en Volkenkunde 142 (1986), no: 2/3, Leiden, 325-327.

Ekadjati, E.S (ed). Direktori Edisi Naskah Nusantara. Jakarta: Yayasan Obor Indonesia, 2000.

Kramadibrata, Dewaki. Metode Penelitian Fiblogi. Paper presented at training on research on religious manuscripts organized by Balai Diklat Tenaga Teknis Ministry of Religious Affairs, Jakarta 1 November 2007 - 6 December 2007.

Lubis, Nabilah. Naskah Teks dan Metode Penelitian Filologi. Jakarta, Forum Kajian Bahasa \& Sastra Arab, Fakultas Adab IAIN Syarif Hidayatullah, 2007.

Marlow, Christine, R. Research Methods for Generalist Social Work. Toro nto: Brooks/Cole, 2001.

Muhaimin, A.G. "Prelude". In Dhofier, Zamakhsari. Tradition and Change: In Indonesian Islamic Education. Jakarta: Ministry of Religious Affair the Republic of Indonesia, 1995.

Pigeaud, Theodore, TH. Literature of Java; Catalogue Raisonne of Javanese Manuscript in The Library of the University of Leiden and Other Publict Collection in the Netherland. Leiden: The Hague, Martinus Nyhoff, 1967.

Poerbatjaraka, M.Ng. Kepustakaan Djawa. Jakarta: Djambatan, 1952. 
IJIMS, Indonesian Joumal oflslam and Muslim Societies, Volume 6, Number1, June 2016: 127-160

Prabowo, D.P. Macapat. Dalam Sedyawati, E.Et-all (ed). Sastra Jawa Suatu Tinjauan Umum. Jakarta: Balai Pustaka, 2001.

Pudjiasuti, Titik. Naskah dan Studi Naskah.Bogor: Akademia, 2006.

Sedyawati, Edi. Et all. (ed). Sastra Jawa Suatu Tinjauan Umum. Jakarta: Balai Pustaka, 2001.

Simuh. Mistik Islam Kejawen Raden Ngabehi Ronggowarsito Suatu study terhadap Serat Wirid Hidayat Jati, 1988.

Simuh. Sufisme Jawa; Transformasi Tasawuf Islam ke Mistik Jawa. Yogyakarta: Bentang Persada, 1999.

Soebardi, S, The Book of Cabolek: A Critical Edition with Introduction, Translation and Notes. A Contribution to the Study of Javanese Mystical Tradition. The Hague: Martinus Nijhoff, 1975.

Suryo, J. "Tradisi Santri dalam Historiografi Java: Pengarug Islam di Jawa." Paper presented at Seminar on Pengaruh Islam terhadap Budaya Jawa, November 30, 2000.

Tim Peneliti Direktorat Jenderal Kebudayaan Jakarta. Serat Dewi Maleka. Jakarta: Proyek Penelitian dan Pengkajian Kebudayaan Nusantara Direktorat Sejarah dan Nilai Tradisional Direktorat Jenderal Kebudayaan, 1992.

Weiringa, Edwin. Catalogue of Malay and Minangkabau Manuscripts in the Library of Leiden Univesity and Other Collection in the Netherlands Volume one. Leiden: Legatum Warnerianum in Leiden University Library, 1998.

Wieringa, Edwin."The Javanese story of Dywi Malyka; A Transformation of a Persian or Perso-Urdu tale." Bijdragen tot de Taat, Land-en Volkenkunde, Vol. 150, No. 3, (1994), 584-587. 